\title{
Optimizing peripheral blood stem cells transplantation outcome through amend relapse and graft failure: a review of current literature
}

\author{
Saeed Mohammadi ${ }^{1}$, Amir Hossein Norooznezhad ${ }^{2}$, Ashraf Malek Mohammadi ${ }^{1}$, Hajar Nasiri $^{1}$, \\ Mohsen Nikbakht ${ }^{1}$, Najmaldin Saki ${ }^{3}$, Mohammad Vaezi $^{1}$, Kamran Alimoghaddam ${ }^{\text {* }}$ \\ and Ardeshir Ghavamzadeh ${ }^{1}$
}

\begin{abstract}
Allogeneic hematopoietic stem cell transplantation (allo-HSCT) has been considered as a valuable approach in treatment of numerous malignant and none malignant hematologic disorders. However, relapse and poor graft function (PGF) after allo-SCT remain to be controversial issues which may affect the transplantation outcome. Relevant articles were searched in MEDLINE database (2000-2016) using keywords and phrases: donor lymphocyte infusions, allogeneic stem cells transplantation, relapsed hematologic malignancies, booster schedules, cell dose, laboratory monitoring protocols and technical aspects of apheresis. Relapse of disease and PGF could be reduced via noting some main points such as choosing the suitable time and patient for donor lymphocyte infusion (DLI) and also determination of patients who ought to candidate for second allogeneic HSCT or for the use of stem cell boost. DLI and stem cell booster are promising treatment strategies noted in this review. Finally, this paper discusses indications and technical aspects of DLI and stem cell booster in hematological malignancies and emphasizes their therapeutic or pre-emptive potentials.
\end{abstract}

Keywords: Peripheral blood, Stem cells transplantation, Relapse, Graft failure

\section{Background}

Over the past decades, allogeneic hematopoietic stem cell transplantation (allo-HSCT) was widely used as a curative choice for refractory and relapsed hematological malignancies in order to achieve a long-term survival [1, 2]. However, relapse and poor graft function (PGF) after transplantation still remained the major cause of treatment failure [3-5]. To enhance the effects of allo-HSCT, variable strategies have been established. According to this point, donor lymphocyte infusion (DLI) as a prophylactic and/or therapeutic strategy is an effective approach

\footnotetext{
*Correspondence: Alimgh@sina.tums.ac.ir; alimogh@sina.tums.ac.ir ${ }^{1}$ Hematology, Oncology and Stem Cell Transplantation Research Center, Tehran University of Medical Sciences, North Kargar Avenue, Tehran 14117-13131, Iran

Full list of author information is available at the end of the article
}

for patients with recurrent hematological malignancies after allo-HSCT through enhancement of graft versus leukemia (GVL) effect. GVL is known as a phenomenon helps patients to fight to their diagnosed disease mostly through $\mathrm{T}$ cells. In a study, inhibition of leukemia colonies growth was seen by donor $\mathrm{T}$ cells reactive to minor histocompatibility antigens [1]. Complications such as graft versus host disease (GVHD) and aplasia may happen after DLI. Prevalence of GVHD with the frequency of 50-60 after DLI, has no correlation with diagnosed disease. Although higher doses of $\mathrm{T}$ cells have more probability to occur. Interestingly, after GVHD a response to DLI as well as a disease free survival is predicted. Aplasia with less prevalence (20-40\% after DLI) in comparison to GVHD has a mortality rate of $5 \%$ which its mechanism is still unclear. According to data the extent of residual host 
hematopoiesis seems to be the predictor of aplasia $[1,6$, 7].

PGF, as another main cause of morbidity and mortality after allo-HSCT, is associated with infections, abnormal bleeding and blood transfusion related complications $[8,9]$. Various therapeutic strategies could potentially improve PGF via stimulation of the already transplanted stem cells with growth factors $[8,9]$, re-transplant from same donor [10], or stem cell boost [11, 12]. In comparison to cited approaches, it seems that stem cell boost without chemotherapy or immunosuppressive conditioning could lead to improvement of survival outcomes [12-14]. Despite the wide use of DLI (therapeutic or pre-emptive) and booster as therapeutic strategies, it still seems to be difficult to achieve a consensus patient selection criteria, treatment schedules, cell dosage, and patient monitoring in different hematopoietic transplantation centers for relapsed and PGF transplanted patients. So, in this review we survey the recent publications in these fields with particular emphasis on mentioned problems and we also intend to prepare a practical guideline.

\section{Therapeutic donor lymphocyte infusion}

This form of DLI has been indicated in patients with relapsed and progressed malignancies. Relapse is defined as the presence of bone marrow (BM) blast cells $\geq 5 \%$ or reappearance of blasts in peripheral blood and/or extramedullary regions $[15,16]$. Major exclusion criteria are listed as uncontrolled infection, renal insufficiency (glomerular filtration rate $<50 \mathrm{~mL} / \mathrm{min}$ ), hepatic impairment (bilirubin elevation to 4.5 -fold above normal range), and malignant liver tumors $[15,17]$.

\section{Chemotherapy + DLI schedules}

After chemotherapy with specific agent(s), in order to achieve complete remission (CR), DLI will be initiated based on the following strategies [18]. First, proper considered time of DLI suddested to be 1-2 week after chemotherapy in order to optimize the synergistic effect of chemotherapy and DLI [19]. Although the definite initial dosage is not confirmed, it has been established that high doses $\left(>10 \times 10^{7} \mathrm{CD} 3 / \mathrm{kg}\right)$ can induce more frequent GVHD. Also, previous efforts have not been successful in decreasing the risk of relapse occurrence and improvement of overall survival in the mentioned high doses. The initial dosage should be $1 \times 10^{6} \mathrm{CD} 3 / \mathrm{kg}$ which is followed by logarithmic escalation [18-21]. In this strategy, the maximum and optimal cell dosage are different based on the type of malignancy. In chronic myeloid leukemia (CML) patients, the cell dosage less than $1 \times 10^{8}$ $\mathrm{T}$ cells/kg is sub-optimal and doses above $4.5 \times 10^{8} \mathrm{~T}$ cells $/ \mathrm{kg}$ might lead to various complications [22-24]. In acute myeloid leukemia (AML) patients, any cell doses less than $1.5 \times 10^{8} \mathrm{~T}$ cells $/ \mathrm{kg}$ may lead to increased rate of failure. In patients with acute lymphoblastic leukemia (ALL), higher response rate was observed in studies using $1-2 \times 10^{8} \mathrm{~T}$ cells $/ \mathrm{kg}[23,25,26]$. interestingly, the higher cell doses were associated with lower clinical response rates. In chronic lympho-proliferative disorders such as lymphomas, using DLI in $0.01-1.0 \times 10^{8} \mathrm{~T}$ cells/ $\mathrm{kg}$ dosage, higher response rates were observed [27-29]. Likewise, in multiple myeloma patients, it seems that there is not a well-defined relationship between cell dosages and response rates with DLI. Cell dosages ranged $0.01-8.2 \times 10^{8} \mathrm{~T}$ cells $/ \mathrm{kg}$ were used in different clinical trials [30-32].

\section{Azacitidine + DLI schedule}

5-Azacytidine and DLI can induce long-term remissions in post allograft relapsed AML patients [33]. In this strategy, DLI was performed for transplanted AML and myelodysplastic syndromes (MDS) patients who were under chemotherapy after eight cycles of 5-azacitidine therapy $\left(100 \mathrm{mg} / \mathrm{m}^{2} /\right.$ day, days $1-5$, every 28 days). After every two cycles of 5-azacitidine, $1-5 \times 10^{6}$ to $1-5 \times 10^{8}$ $\mathrm{CD}^{+}{ }^{+}$cells/kg were infused $[17,34]$.

\section{Modified lymphodepletion (LD) + DLI schedule}

This method is based on lymphocyte regulatory $\mathrm{T}$ cell ( $\mathrm{T}$ reg) suppression during the $L D$ process [35]. To minimize the risk of severe GVHD incidence, the following strategies could be considered. First, cyclophosphamide (CY) and fludarabine (FLU) should be administered at the doses of $600 \mathrm{mg} / \mathrm{m}^{2}$ on day 1 and $25 \mathrm{mg} / \mathrm{m}^{2} /$ day on days $1-3$, respectively. At the second step, donor lymphocytes were infused in a fixed high dose of $1 \times 10^{8} \mathrm{CD} 3+$ cells/ $\mathrm{kg}, 48 \mathrm{~h}$ after the last FLU injection. Finally, patients who received chemotherapy along with the DLI (chemo-DLI) showed more frequent episodes acute GVHD, particularly in lower gastro-intestinal (GI) system [35-37].

\section{Technical tips for DLI procedure in chemotherapy DLI} When low-dose of DL is requested $\left(10^{4}-10^{5} \mathrm{~T}\right.$-cells $\left./ \mathrm{kg}\right)$, small aliquot of freshly collected blood from a related donor are needed. According to National Systems guidelines, if all tests for transfusion transmitted diseases were negative in sample collection time, this product could be readily used for patients. Usually, small aliquots of donor-recipients whole blood (1-2 mL), with major $A B O$ incompatibilities do not seem to be life-threatening. When a high dose of DLI is requested, the product may be harvested through normal or large-volume leukapheresis $[38,39]$. A summary of therapeutic DLI strategies is shown in Fig. 1. 


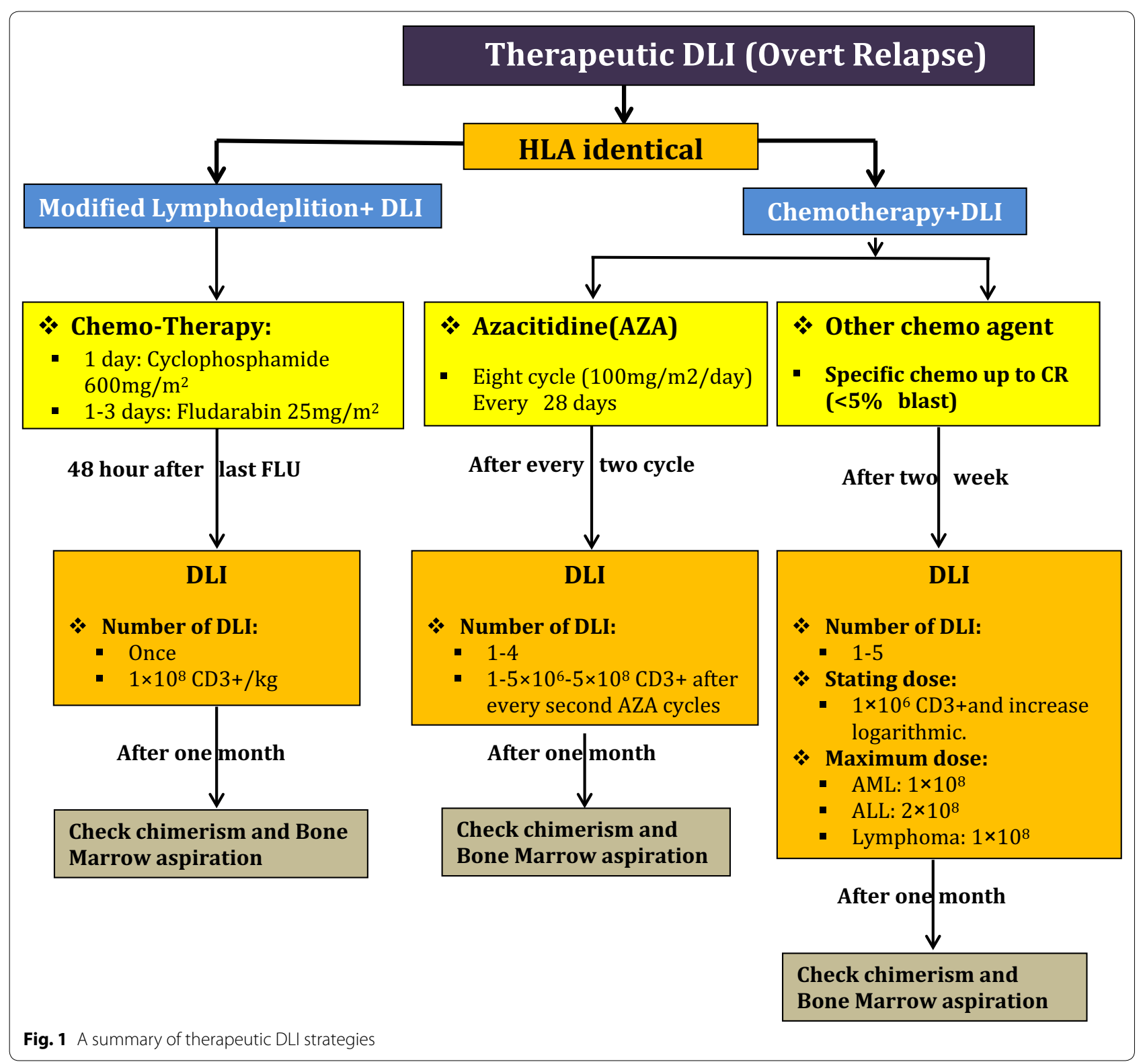

\section{Pre-emptive/prophylactic donor lymphocyte infusion in HLA identical transplantation}

Pre-emptive/prophylactic DLI is an acceptable choice especially for those patients who suffer from refractory or relapsed malignancies before transplantation, patients allo-grafted with active uncontrolled disease, patients who received transplantation in CR1 or CR1 $>1$, AML and ALL patients with high risk for relapse due to the positive minimal residual diseases [40] and also allograft transplanted patients with positive positron emotion tomography (PET) scan suffering from lymphoma. In these circumstances, DLI could be more effective because of the low tumor burden [20]. It seems that there is no advantage of administering DLI in the early stage of molecular relapse in patients who received allogeneic stem cell transplantation for CML [41-46]. Prophylactic DLI has not been administered in several situations including: the onset of GVHD, uncontrolled infections, early relapse, engraftment failure and organ failure [47]. In this strategy, immunomodulation consists of early reduction of immunosuppression medication which was then followed by DLI. In patients with appearance of GVHD, tentative tapering of immunosuppressive therapy should be considered. On the other hand, in patients with 
no incidence of GVHD, immunosuppression should be discontinued and donors would be eligible for lymphoapheresis [41-46].

\section{Treatment schedule for preemptive/prophylactic un-modified DLI based on molecular markers in HLA identical transplantation}

In this strategy, Wilms tumor-1 (WT1) gene expression exceeding 100 copies $/ 10^{4}$ abelson murine leukemia-1 (ABL1) in bone marrow (BM) or WT- $1 \geq 5$ copies $/ 10^{4}$ ABL1 in peripheral blood, with $\mathrm{BM}$ in remission status ( $<5 \%$ blasts simultaneously with morphology and cytometry symptoms) is surrogate for starting DLI [45, 48]. In absence of GVHD for HLA identical siblings transplantation, the starting dosage is $1 \times 10^{6} / \mathrm{kg} \mathrm{CD} 3+$ cells and subsequently, half log increments every 30-60 days until MRD becomes negative. In unrelated transplant recipients, the initial dosage is $1 \times 10^{5} / \mathrm{kg}$ CD3 + cells, along with half $\log$ increments every 30-60 days until MRD becomes negative. If GVHD developed after DLI, the program should be ceased until it would be completely suppressed [44-46].

\section{Treatment schedule for preemptive/prophylactic un-modified DLI for high risk patients}

This DLI strategy has been applied in two clinical trials for ALL patients. The median time and CD3+ cell dosage after HSCT are 60-185 days and 1.5-3 × $10^{6}$ cells, respectively $[49,50]$.

\section{Modified prophylactic DLI (mpDLI) or G-CSF primed in HLA identical transplantation}

This strategy might take advantage by using donor's G-CSF-mobilized peripheral blood progenitor cells (GPBPCs) instead of their steady lymphocytes. In this method, infused cells have super anti-leukemia effects. Likewise, this approach may be accompanied by a reduction in infusion-related GVHD and also it is rarely challenged by the risk of pancytopenia [51, 52]. MRD-based modified DLI intervention is associated with transplant outcomes improvement. MRD could be evaluated using qualitative nested PCR for immunoglobulin heavy chain (IgH) VDJ, TCR gene rearrangement, WT1 expression and leukemia associated immunophenotypes (LAIP). Combination of these biomarkers is more sensitive in relapse prediction than each of WT1 or LAIP separately after transplantation $[48,51,52]$. This form of DLI is indicated after HLA-identical HSCT for patients with unfavorable cytogenetic abnormalities and also acute leukemia in more than CR1 status or in the non-remission state. Likewise, this strategy is indicated in CML in both accelerated phase (AP) and blast phase (BP) as well as myeloproliferative disorders with unfavorable cytogenetic abnormalities such as 8p11 [50-54] (Table 1).

\section{Treatment schedule for (mpDLI) or G-CSF primed prophylactic DLI (without MRD monitoring)}

Short-term immunosuppressive agents (cyclosporine A or methotrexate (MTX) $10 \mathrm{mg} /$ week for 2-4 weeks) are in use for prevention of DLI associated GVHD. DLI could be considered for use from days 45 to 120 after transplantation in patients without recurrence of leukemia and GVHD. In some conditions such as onset of GVHD, uncontrolled persistent infections longer than 60 days and postponement of consent, it has been suggested to avoid performing prophylactic DLI. $1 \times 10^{8}$ $\mathrm{MNCs} / \mathrm{kg}$ seems to be a proper initial cell dosage for DLI in patients who have received DLI before day 90 after transplantation. Cyclosporine A (CsA) should be continued for 2 weeks and it tapered within 4 weeks and discontinued after then if no DLI-associated GVHD occurs. In patients who received DLI after day 90 of transplantation, all immunosuppressive agents should be stopped for at least 2 weeks before DLI infusion in in order to prevent GVHD. These patients should take oral CsA or MTX $10 \mathrm{mg} /$ week (single dose) for 2-4 weeks after DLI intended for prevention of DLI-associated GVHD [47, 53].

\section{Treatment schedule for (mpDLI) or G-CSF primed prophylactic DLI (MRD base)}

In this strategy, WT1 gene expression more than 100 copies $/ 10^{4}$ ABL1 in BM or WT1 $\geq 5$ copies/10 4 ABL1 in peripheral blood, together with bone marrow remission ( $<5 \%$ blasts), and concordance of morphology and flow cytometry (FCM) is surrogate for starting DLI. Positive FCM is defined as $>0.001 \%$ of cells with a leukemia-associated immunophenotypes (LAIP phenotype in $\geq 1 \mathrm{BM}$ samples after transplantation) [48]. The immune intervention before DLI is determined as a post transplantation immune suppression which should be immediately tapered and then discontinued in patients with MRD $+\leq 100$ days after transplantation. Immune suppression was immediately discontinued in MRD+ patients in whom more than 100 days have been passed from their transplantation. In HLA identical siblings recipients, DLI should be started with $1 \times 10^{8} / \mathrm{kg}$ MNC and consequently, with half log increments every 30-60 days until MRD becomes negative, in the absence of GVHD. In unrelated transplant recipients, DLI should be started with $1 \times 10^{8} / \mathrm{kg} \mathrm{MNC}$ and subsequently with half log increments every 30-60 days until MRD becomes negative. If GVHD develops after DLI, the program should be stopped until it resolves 


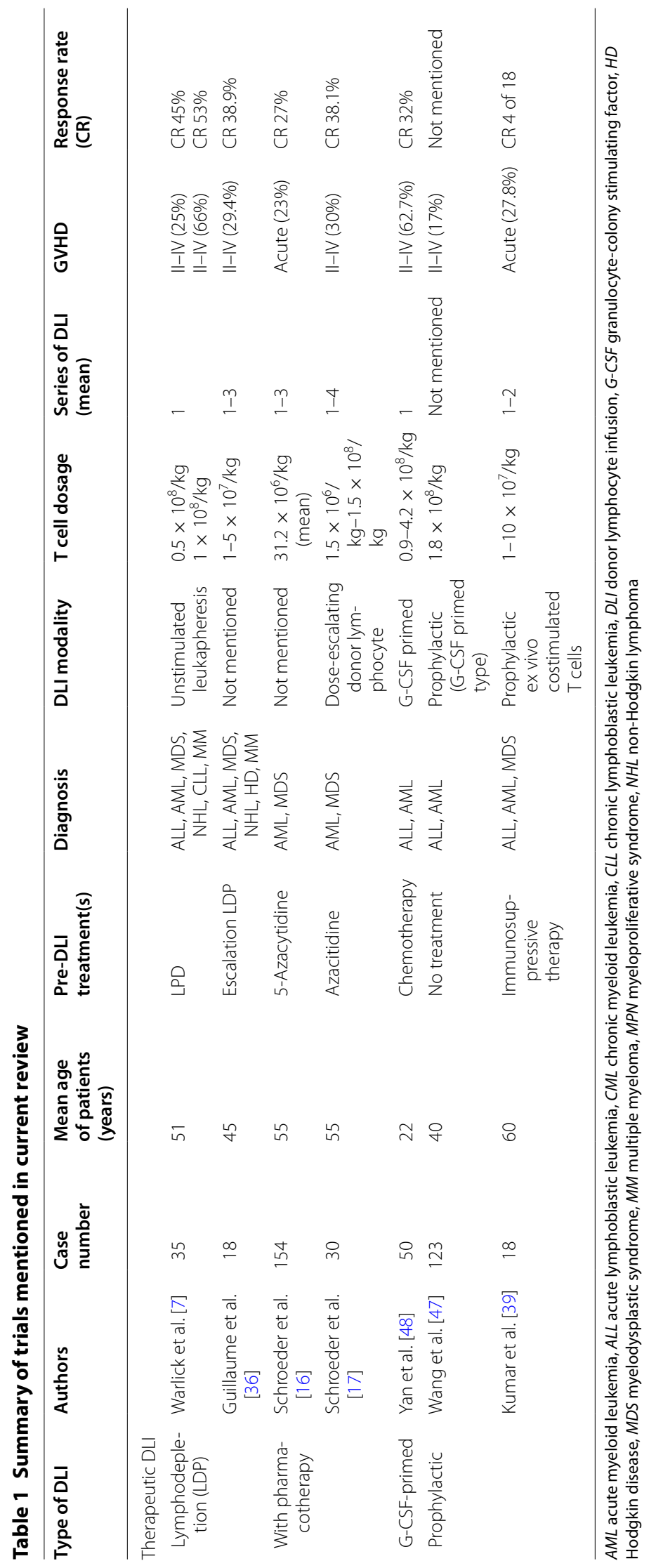


$[48,55]$. After DLI, patients should receive immunosuppressive medications such as CsA or MTX in order to prevent GVHD. CsA is usually started at the dosage of $2.5 \mathrm{mg} / \mathrm{kg} /$ day and it must be adjusted to maintain plasma concentration of $>100 \mathrm{ng} / \mathrm{mL}$. MTX should be started at $10 \mathrm{mg}$ IV on days $1,4,8$, and continued weekly for 2-6 weeks. In patients receiving DLI from an HLA-identical related donor, GVHD prophylaxis should be received for 2-4 weeks. In patients receiving DLI from an HLA-matched unrelated or HLA-haploidentical donor, GVHD prophylaxis regimen should be prescribed for 4-6 weeks at the discretion of the well trained physicians which usually depends on patient's GVHD status after DLI $[48,55]$.

Treatment schedule for pre-emptive/prophylactic unmodified DLI for mix chimerism (MC) patients

This DLI strategy has been applied in three clinical trials for lymphoma, AML and MDS patients. The median time after HSCT ranged from 35 to 287 days and the median CD3+ cell dosage ranged from $1 \times 10^{7}$ to $5.7 \times 10^{7}$ in these studies $[42,56,57]$.

\section{Technical tips for DLI procurement}

G-CSF stimulated peripheral blood stem cells should be harvested through leukopheresis and DLI might be obtained from negative fraction of CD34+ hematopoietic stem cells selection. Based on many published reports, differences among last generation devices are minimum; as a result, most of cell separator devices (such as Spectraoptia ${ }^{\circledR}$ and Fresenius Com. Tec ${ }^{\circledR}$ ) are able to collect highly enriched lymphocyte fraction with very low erythrocyte pollution and in some cases reduced platelet content. These aliquots are therefore maintained frozen until thawing to infusion $[58,59]$.

A summary of prophylactic/pre-emptive DLI strategies in HLA identical transplantation is shown in Fig. 2.

\section{DLI for haploidentical transplantation \\ Therapeutic donor lymphocyte infusion (t-DLI) in haploidentical transplantation \\ Chemothrerapy-DLI with Baltimore platform with post-transplant cyclophosphamide (PT-Cy)}

PT-Cy has been used for relapsed patients after haploidentical HSCT. The initial used CD3+ dosage is $1 \times 10^{5} /$

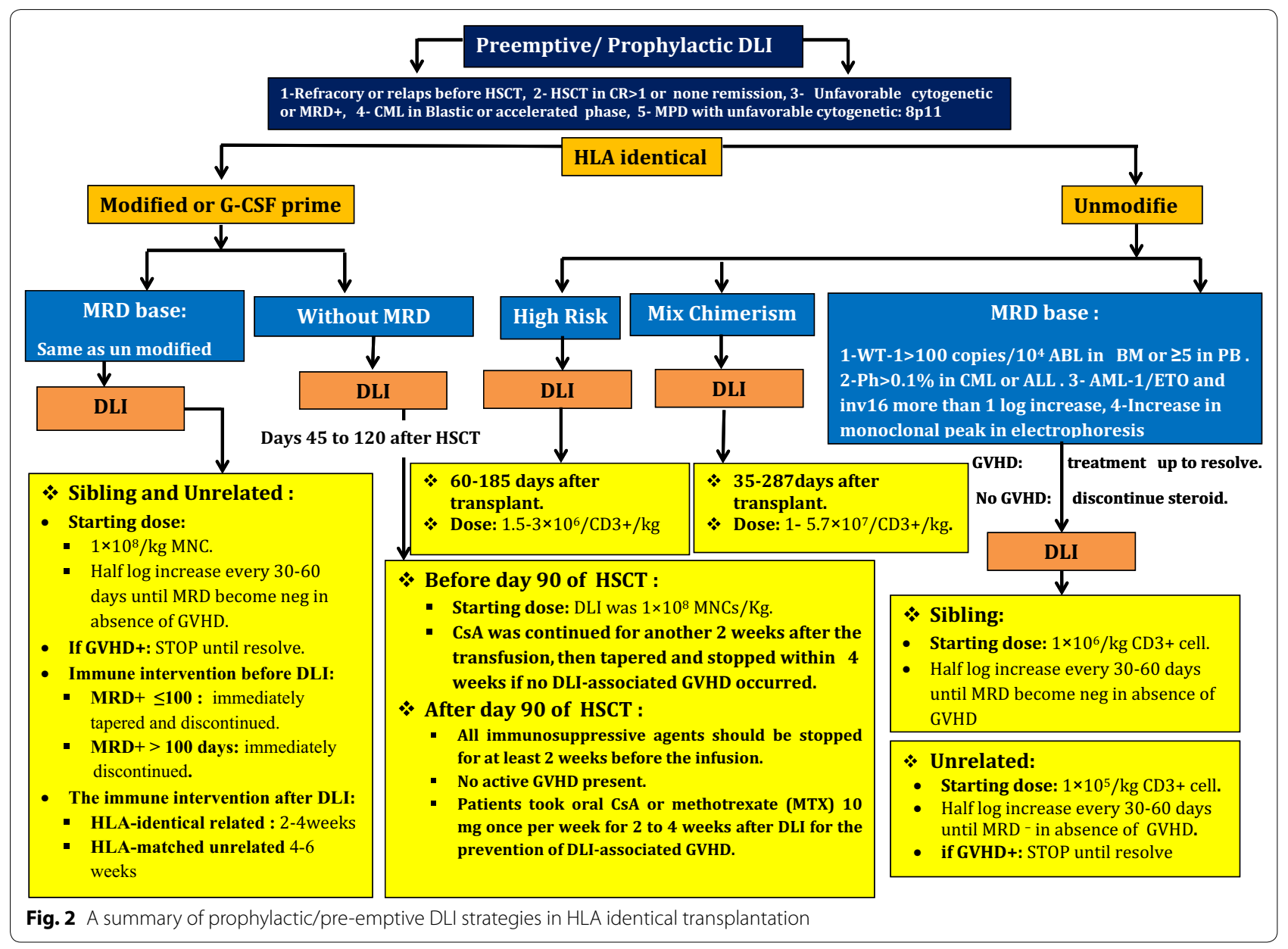


$\mathrm{kg}$ of recipient and all immunosuppression agents should be discontinued [60, 61].

\section{Pre-emptive/prophylactic DLI (pDLI) in haploidentical transplantation MRD based un-manipulated DLI (without GCS-F)}

This strategy is applied for AML patients with MRD relapse. Firstly, patients receive a low dosage of $\mathrm{CD} 3+$ $\left(1 \times 10^{3} / \mathrm{kg}\right)$ and then a gradually increased dosage up to $1 \times 10^{5} / \mathrm{kg}-1 \times 10^{6} / \mathrm{kg}$ would be used $[61,62]$.

\section{Treatment schedule for G-CSF primed prophylactic DLI (without MRD monitoring)}

Short-term immunosuppressive agents [CsA or MTX $10 \mathrm{mg} /$ week (single dose) for 2-4 weeks] should be administered in order to prevent DLI associated GVHD. DLI could be considered from days 45 to 120 after transplantation in patients without recurrence of leukemia and GVHD [53]. The principal reasons for this delayed prophylactic DLI administration are introduced as GVHD occurrence, uncontrolled infections (lasting longer than 60 days), and postponement of consent. As a key point, clinicians should remember to eradicate serious infections before DLI accomplishment. Furthermore, no serious organ failure should be detected. The initial cell dosage for DLI is $1 \times 10^{8} \mathrm{MNC} / \mathrm{kg}$ for patients who are candidate to receive DLI before day 90 after transplantation. Also, CsA should be continued for 2 additional weeks. After that, CsA should taper and finally be discontinued within 4 weeks if no DLI associated GVHD occures. For patients who have received DLI after day 90, all immunosuppressive agents should be stopped for at least 2 weeks before the DLI infusion when no active GVHD is present. Oral CsA or MTX $10 \mathrm{mg} /$ week (single dose) for 2-4 weeks after DLI is advised in order to prevent DLI-associated GVHD in these patients [47, 51-54, $60,61]$.

\section{Technical tips for DLI procurement}

G-CSF stimulated peripheral blood stem cells should be harvested through leukopheresis and DLI might be obtained from the negative fraction of the CD34+ hematopoietic stem cell selection. These aliquots are preserved and thawed at different intervals for infusion [58, 59]. A summary of prophylactic/pre-emptive DLI strategies in HLA haploidentical transplantation is shown in Fig. 3.

\section{Evaluation of response to DLI}

The best response rates are observed, respectively, in patients with CML, lymphomas, multiple myeloma and acute leukemia. The responses in patients suffering from CML are durable in comparison to other patients with other malignancies in chronic phase. CML patients show better response rather in accelerated/blastic phase. Patients with only molecular and cytogenetic relapses always went into remission with DLI, while in patients with chronic phase, hematologic relapse remission rate is about $75 \%$. Continuing DLI for patients with merely cytogenetic/molecular relapse may be helpful to achieve the least remission rates. In patients with lymphoma, highest response rates have been observed in indolent lymphomas, while aggressive lymphomas contained to have lower response rates. Significant responses can be attained in more aggressive lymphomas; however, chemotherapy seems to be prerequisite for success [1, 63-65].

\section{Cell booster in poor graft function transplantation Booster indications}

Booster has indication in the following situations:

1. Primary graft failure (PGF) is defined as cytopenia occurrence in at least two hematopoietic lines beyond the 21st day after transplantation. In this circumstance, neutrophil count $\leq 1.5 \times 10^{9} / \mathrm{L}$, platelet count $\leq 30 \times 10^{9} / \mathrm{L}$ and $\mathrm{Hb} \leq 8.5 \mathrm{~g} / \mathrm{dL}$. Engraftment of neutrophils is determined as the first of three consecutive days when absolute neutrophil count (ANC) was $>0.5 \times 10^{9} / \mathrm{L}$ without G-CSF ( $5 \mu \mathrm{kg} / \mathrm{kg}$ body weight) stimulation. Engraftment of platelets is defined in the first of three consecutive days when the platelet count is $\geq 20 \times 10^{9} / \mathrm{L}$ (independent from platelet substitution) [12-14, 66, 67].

2. Secondary graft failure is defined as BM hypoplasia $(<10 \%$ cellularity) after engraftment which in this situation patient requires frequent (more than once a week) platelet transfusions. Among other criterias for secondary graft failure are ANC of less than $0.5 \times 10^{9} / \mathrm{L}$ without growth factor therapy beyond day 60 in presence of full donor chimerism and in absence of severe GVHD, CMV reactivation, relapse or drug-related myelo-suppression [12-14, $66,67]$. 


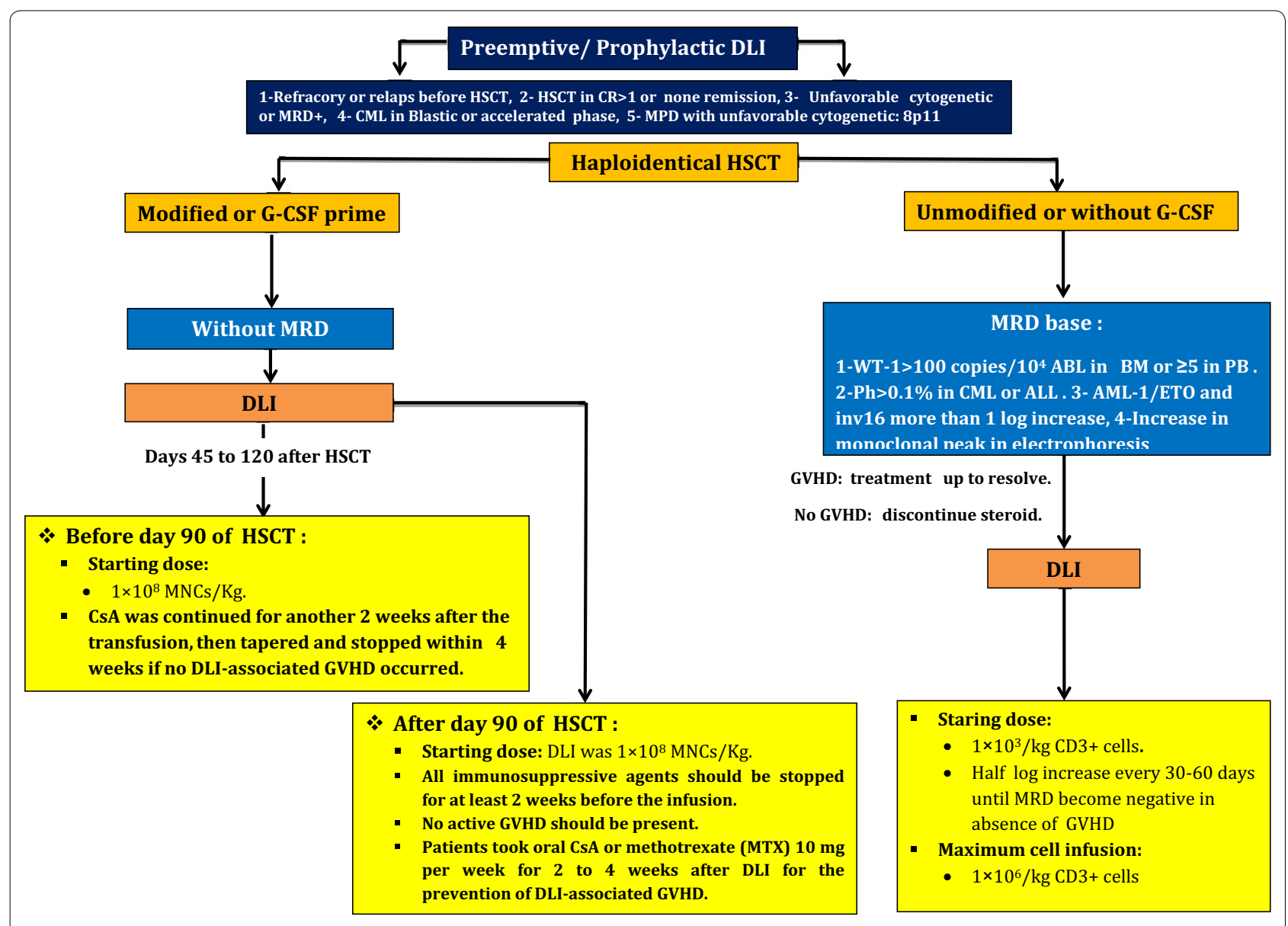

Fig. 3 A summary of prophylactic/pre-emptive DLI strategies in HLA haploidentical transplantation

\section{Treatment schedule for booster}

PBSC donors should be stimulated with G-CSF $(10 \mu \mathrm{g} /$ $\mathrm{kg} /$ day for 4 days) prior to leukapheresis. Based on recent data, the median amount of CD34 cells is suggested to be $3.4 \times 10^{6} / \mathrm{kg}$ for a successful leukopheresis. Also, the median infused MNCs dosage is $2.55 \times 10^{8} /$ $\mathrm{kg}$ with (CsA + MTX or CsA + prednisolone or CsA + MTX + prednisolone) or without immunosuppressive treatment $[4,12,13,66,67]$. A summary of stem cell boost (booster) strategy for poor graft function after allogeneic transplantation is shown in Fig. 4.

\section{Conclusions}

DLI and booster are two main therapeutic opportunities for precluding or treating relapse and PGF of hematologic malignancies after allo-HSCT. Likewise, DLI has been used in advanced-stages of malignancies and augmenting immune reconstitution, although, GVHD considered as a major complication of using DLI in clinic. Hence, a good strategy would be to enhance GVL effect and in the intervening time to minimize GVHD. On the most important way to differentiate between GVHD and GVT is DLI using tumor specific donor lymphocytes [19]. Also, it has been showed that the dose-escalating strategy could use as a method for management of balance between GVL and GVHD after DLI [17].

The recent presented data on DLI and booster studies certainly provide valuable information for optimizing these therapeutic strategies in order to be applied in different clinical settings. However, the protocols for prophylactic and therapeutic DLIs may require some modifications. Despite the recent published data on DLI 


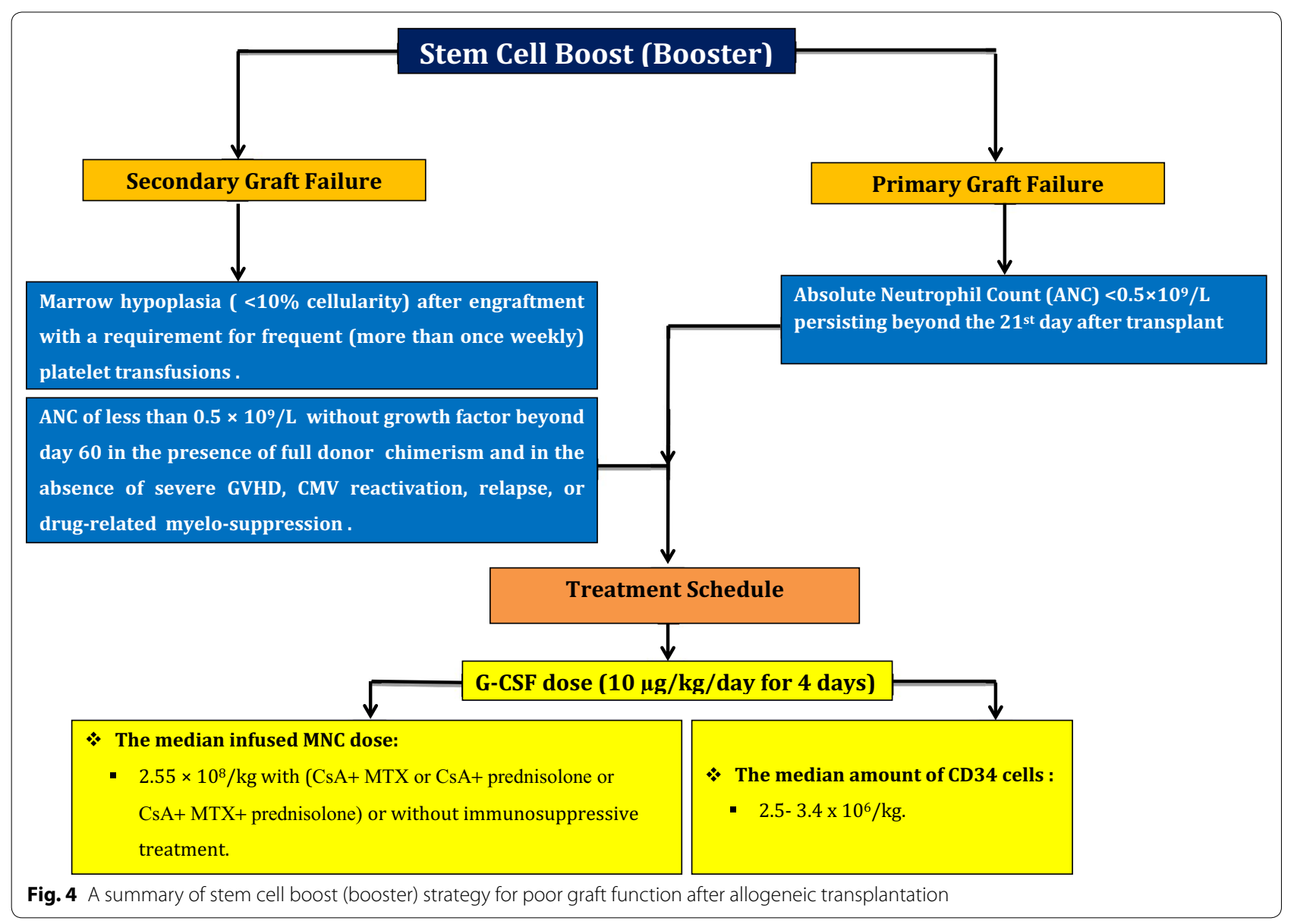

and booster up to now, it seems the dosage of infused cells, the timing and frequency of administration, and the continuity of treatment still need to be optimized for any given clinical setting.

\section{Authors' contributions}

All authors had contributions to conception and design, data collection, article searching and interpretation of data as well as being involved in drafting the manuscript and revising. Any difference in order of authors' name is only due to the workload. Also, authors have given final approval of the version to be published. Each author has participated sufficiently in different part of this review to take public responsibility for appropriate portions of the content. Authors agreed to be accountable for all aspects of the work in ensuring that questions related to the accuracy or integrity of any part of the work are appropriately investigated and resolved. All authors read and approved the final manuscript.

\section{Author details}

${ }^{1}$ Hematology, Oncology and Stem Cell Transplantation Research Center, Tehran University of Medical Sciences, North Kargar Avenue, Tehran 14117-13131, Iran. ${ }^{2}$ Regenerative Medicine Research Center, Kermanshah University of Medical Sciences, Kermanshah, Iran. ${ }^{3}$ Thalassemia and Hemoglobinopathy Research Center, Ahvaz Jundishapur University of Medical Sciences, Ahvaz, Iran.

\section{Acknowledgements}

Not applicable.

\section{Competing interests}

The authors declare that they have no competing interests.

Availability of data and materials

Not applicable.

\section{Consent for publication}

Not applicable.

Ethics approval and consent to participate

Not applicable.

\section{Funding}

This work was supported by Hematology, Oncology and Stem Cell Transplantation Research center, Tehran University of Medical Sciences, Tehran, Iran.

\section{Publisher's Note}

Springer Nature remains neutral with regard to jurisdictional claims in published maps and institutional affiliations.

Received: 26 April 2017 Accepted: 24 July 2017

Published online: 09 August 2017

\section{References}

1. Deol A, Lum LG. Role of donor lymphocyte infusions in relapsed hematological malignancies after stem cell transplantation revisited. Cancer Treat Rev. 2010;36:528-38. 
2. Bazarbachi A, Labopin M, Ghavamzadeh A, Giebel S, Al-Zahrani H, Ladeb $\mathrm{S}$, et al. Allogeneic matched-sibling hematopoietic cell transplantation for AML: comparable outcomes between Eastern Mediterranean (EMBMT) and European (EBMT) centers. Bone Marrow Transplant. 2013:48:1065-9.

3. Oran B, de Lima M. Prevention and treatment of acute myeloid leukemia relapse after allogeneic stem cell transplantation. Curr Opin Hematol. 2011;18:388-94.

4. Olsson R, Remberger M, Schaffer M, Berggren DM, Svahn BM, Mattsson J, et al. Graft failure in the modern era of allogeneic hematopoietic SCT. Bone Marrow Transplant. 2013;48:537-43.

5. Schriber J, Agovi MA, Ho V, Ballen KK, Bacigalupo A, Lazarus HM, et al. Second unrelated donor hematopoietic cell transplantation for primary graft failure. Biol Blood Marrow Transplant. 2010;16:1099-106.

6. Michallet AS, Nicolini F, Furst S, Le QH, Dubois V, Hayette S, et al. Outcome and long-term follow-up of alloreactive donor lymphocyte infusions given for relapse after myeloablative allogeneic hematopoietic stem cell transplantations (HSCT). Bone Marrow Transplant. 2005;35:601-8.

7. Warlick ED, DeFor T, Blazar BR, Burns L, Verneris MR, Ustun C, et al. Successful remission rates and survival after lymphodepleting chemotherapy and donor lymphocyte infusion for relapsed hematologic malignancies postallogeneic hematopoietic cell transplantation. Biol Blood Marrow Transplant. 2012;18:480-6.

8. Gaya A, Urbano-Ispizua A, Fernandez-Aviles F, Salamero O, Roncero $J M$, Rovira M, et al. Anemia associated with impaired erythropoietin secretion after allogeneic stem cell transplantation: incidence, risk factors, and response to treatment. Biol Blood Marrow Transplant. 2008;14:880-7.

9. Ringden O, Hassan Z, Karlsson H, Olsson R, Omazic B, Mattsson J, et al. Granulocyte colony-stimulating factor induced acute and chronic graftversus-host disease. Transplantation. 2010;90:1022-9.

10. Guardiola P, Kuentz M, Garban F, Blaise D, Reiffers J, Attal M, et al. Second early allogeneic stem cell transplantations for graft failure in acute leukaemia, chronic myeloid leukaemia and aplastic anaemia. French Society of Bone Marrow Transplantation. Br J Haematol. 2000;111:292-302.

11. Mohty M, Faucher C, Chabannon C, Vey N, Stoppa AM, Ladaique P, et al. CD34(+) immunoselected cells for poor graft function following allogeneic BMT. Cytotherapy. 2000;2:367-70.

12. Milone G, Tornello A, Leotta S, Poidomani M, Mercurio S, Farsaci B, et al. CD34+ selected haematopoietic stem cell (HSC) not preceded by any immunosuppressive therapy as effective treatment for graft failure. Bone Marrow Transplant. 2005;35:521-2 (author reply 2)

13. Klyuchnikov E, El-Cheikh J, Sputtek A, Lioznov M, Calmels B, Furst S, et al. CD34(+)-selected stem cell boost without further conditioning for poor graft function after allogeneic stem cell transplantation in patients with hematological malignancies. Biol Blood Marrow Transplant. 2014;20:382-6.

14. Oyekunle A, Koehl U, Schieder H, Ayuk F, Renges H, Fehse N, et al. CD34(+)-selected stem cell boost for delayed or insufficient engraftment after allogeneic stem cell transplantation. Cytotherapy. 2006;8:375-80.

15. Dohner H, Estey EH, Amadori S, Appelbaum FR, Buchner T, Burnett AK, et al. Diagnosis and management of acute myeloid leukemia in adults: recommendations from an international expert panel, on behalf of the European LeukemiaNet. Blood. 2010;115:453-74.

16. Schroeder T, Rachlis E, Bug G, Stelljes M, Klein S, Steckel NK, et al. Treatment of acute myeloid leukemia or myelodysplastic syndrome relapse after allogeneic stem cell transplantation with azacitidine and donor lymphocyte infusions - a retrospective multicenter analysis from the German Cooperative Transplant Study Group. Biol Blood Marrow Transplant. 2015:21:653-60.

17. Schroeder T, Czibere A, Platzbecker U, Bug G, Uharek L, Luft T, et al. Azacitidine and donor lymphocyte infusions as first salvage therapy for relapse of AML or MDS after allogeneic stem cell transplantation. Leukemia. 2013;27:1229-35

18. Levine JE, Barrett AJ, Zhang MJ, Arora M, Pulsipher MA, Bunin N, et al. Donor leukocyte infusions to treat hematologic malignancy relapse following allo-SCT in a pediatric population. Bone Marrow Transplant. 2008:42:201-5.

19. Chang $X$, Zang $X$, Xia CQ. New strategies of DLI in the management of relapse of hematological malignancies after allogeneic hematopoietic SCT. Bone Marrow Transplant. 2016;51:324-32.
20. Castagna L, Sarina B, Bramanti S, Perseghin P, Mariotti J, Morabito L. Donor lymphocyte infusion after allogeneic stem cell transplantation. Transfus Apher Sci. 2016;54:345-55.

21. Bar M, Sandmaier BM, Inamoto Y, Bruno B, Hari P, Chauncey T, et al. Donor lymphocyte infusion for relapsed hematological malignancies after allogeneic hematopoietic cell transplantation: prognostic relevance of the initial CD3+ T cell dose. Biol Blood Marrow Transplant. 2013;19:949-57.

22. Porter DL, Collins RH Jr, Hardy C, Kernan NA, Drobyski WR, Giralt S, et al. Treatment of relapsed leukemia after unrelated donor marrow transplantation with unrelated donor leukocyte infusions. Blood. 2000;95:1214-21.

23. Dazzi F, Szydlo RM, Cross NC, Craddock C, Kaeda J, Kanfer E, et al. Durability of responses following donor lymphocyte infusions for patients who relapse after allogeneic stem cell transplantation for chronic myeloid leukemia. Blood. 2000;96:2712-6.

24. Shiobara S, Nakao S, Ueda M, Yamazaki H, Takahashi S, Asano S, et al. Donor leukocyte infusion for Japanese patients with relapsed leukemia after allogeneic bone marrow transplantation: lower incidence of acute graft-versus-host disease and improved outcome. Bone Marrow Transplant. 2000;26:769-74.

25. Choi SJ, Lee JH, Lee JH, Kim S, Seol M, Lee YS, et al. Treatment of relapsed acute myeloid leukemia after allogeneic bone marrow transplantation with chemotherapy followed by G-CSF-primed donor leukocyte infusion: a high incidence of isolated extramedullary relapse. Leukemia. 2004;18:1789-97.

26. Schmid C, Labopin M, Nagler A, Bornhauser M, Finke J, Fassas A, et al. Donor lymphocyte infusion in the treatment of first hematological relapse after allogeneic stem-cell transplantation in adults with acute myeloid leukemia: a retrospective risk factors analysis and comparison with other strategies by the EBMT Acute Leukemia Working Party. J Clin Oncol. 2007;25:4938-45.

27. Anderlini P, Acholonu SA, Okoroji GJ, Andersson BS, Couriel DR, De Lima $\mathrm{MJ}$, et al. Donor leukocyte infusions in relapsed Hodgkin's lymphoma following allogeneic stem cell transplantation: $\mathrm{CD} 3+$ cell dose, GVHD and disease response. Bone Marrow Transplant. 2004;34:511-4.

28. Bishop MR, Dean RM, Steinberg SM, Odom J, Pavletic SZ, Chow C, et al. Clinical evidence of a graft-versus-lymphoma effect against relapsed diffuse large B-cell lymphoma after allogeneic hematopoietic stem-cell transplantation. Ann Oncol. 2008;19:1935-40.

29. Bloor AJ, Thomson K, Chowdhry N, Verfuerth S, Ings SJ, Chakraverty R, et al. High response rate to donor lymphocyte infusion after allogeneic stem cell transplantation for indolent non-Hodgkin lymphoma. Biol Blood Marrow Transplant. 2008;14:50-8.

30. Bensinger WI, Buckner CD, Anasetti C, Clift R, Storb R, Barnett T, et al. Allogeneic marrow transplantation for multiple myeloma: an analysis of risk factors on outcome. Blood. 1996;88:2787-93.

31. Lokhorst HM, Schattenberg A, Cornelissen JJ, van Oers MH, Fibbe W, Russell I, et al. Donor lymphocyte infusions for relapsed multiple myeloma after allogeneic stem-cell transplantation: predictive factors for response and long-term outcome. J Clin Oncol. 2000;18:3031-7.

32. van de Donk NW, Kroger N, Hegenbart U, Corradini P, San Miguel JF, Goldschmidt $\mathrm{H}$, et al. Prognostic factors for donor lymphocyte infusions following non-myeloablative allogeneic stem cell transplantation in multiple myeloma. Bone Marrow Transplant. 2006;37:1135-41.

33. Steinmann J, Bertz H, Wasch R, Marks R, Zeiser R, Bogatyreva L, et al. 5-Azacytidine and DLI can induce long-term remissions in AML patients relapsed after allograft. Bone Marrow Transplant. 2015;50:690-5.

34. Craddock C, Labopin M, Robin M, Finke J, Chevallier P, Yakoub-Agha I, et al. Clinical activity of azacitidine in patients who relapse after allogeneic stem cell transplantation for acute myeloid leukemia. Haematologica. 2016;101:879-83.

35. Miller JS, Weisdorf DJ, Burns LJ, Slungaard A, Wagner JE, Verneris MR, et al. Lymphodepletion followed by donor lymphocyte infusion (DLI) causes significantly more acute graft-versus-host disease than DLI alone. Blood. 2007;110:2761-3

36. Guillaume T, Gaugler B, Chevallier P, Delaunay J, Ayari S, Clavert A, et al. Escalated lymphodepletion followed by donor lymphocyte infusion can induce a graft-versus-host response without overwhelming toxicity. Bone Marrow Transplant. 2012:47:1112-7.

37. He F, Warlick E, Miller JS, MacMillan M, Verneris MR, Cao Q, et al. Lymphodepleting chemotherapy with donor lymphocyte infusion 
post-allogeneic HCT for hematological malignancies is associated with severe, but therapy-responsive aGvHD. Bone Marrow Transplant. 2016;51(8):1107-12

38. Or R, Hadar E, Bitan M, Resnick IB, Aker M, Ackerstein A, et al. Safety and efficacy of donor lymphocyte infusions following mismatched stem cell transplantation. Biol Blood Marrow Transplant. 2006;12:1295-301.

39. Kumar AJ, Hexner EO, Frey NV, Luger SM, Loren AW, Reshef R, et al. Pilot study of prophylactic ex vivo costimulated donor leukocyte infusion after reduced-intensity conditioned allogeneic stem cell transplantation. Biol Blood Marrow Transplant. 2013;19:1094-101.

40. Baron F, Beguin Y. Prophylactic donor lymphocyte infusion in patients with high-risk acute myeloid leukemia: ready for prime time? Bone Marrow Transplant. 2016;51:640-2.

41. de Lima M, Bonamino M, Vasconcelos Z, Colares M, Diamond H, Zalcberg I, et al. Prophylactic donor lymphocyte infusions after moderately ablative chemotherapy and stem cell transplantation for hematological malignancies: high remission rate among poor prognosis patients at the expense of graft-versus-host disease. Bone Marrow Transplant. 2001;27:73-8.

42. Dey BR, McAfee S, Colby C, Sackstein R, Saidman S, Tarbell N, et al. Impact of prophylactic donor leukocyte infusions on mixed chimerism, graftversus-host disease, and antitumor response in patients with advanced hematologic malignancies treated with nonmyeloablative conditioning and allogeneic bone marrow transplantation. Biol Blood Marrow Transplant. 2003;9:320-9.

43. Chalandon Y, Passweg JR, Guglielmi C, lacobelli S, Apperley J, Schaap NP, et al. Early administration of donor lymphocyte infusions upon molecular relapse after allogeneic hematopoietic stem cell transplantation for chronic myeloid leukemia: a study by the Chronic Malignancies Working Party of the EBMT. Haematologica. 2014;99:1492-8.

44. Pozzi S, Geroldi S, Tedone E, Luchetti S, Grasso R, Colombo N, et al. Leukaemia relapse after allogeneic transplants for acute myeloid leukaemia: predictive role of WT1 expression. Br J Haematol. 2013;160:503-9.

45. Malagola M, Skert C, Ruggeri G, Turra A, Ribolla R, Cancelli V, et al. Peripheral blood WT1 expression predicts relapse in AML patients undergoing allogeneic stem cell transplantation. Biomed Res Int. 2014;2014:123079.

46. Di Grazia C, Pozzi S, Geroldi S, Grasso R, Miglino M, Colombo N, et al. Wilms tumor 1 expression and pre-emptive immunotherapy in patients with acute myeloid leukemia undergoing an allogeneic hemopoietic stem cell transplantation. Biol Blood Marrow Transplant. 2016;22:1242-6.

47. Wang Y, Liu DH, Fan ZP, Sun J, Wu XJ, Ma X, et al. Prevention of relapse using DLI can increase survival following HLA-identical transplantation in patients with advanced-stage acute leukemia: a multi-center study. Clin Transplant. 2012;26:635-43.

48. Yan $\mathrm{CH}$, Liu DH, Liu KY, Xu LP, Liu YR, Chen H, et al. Risk stratificationdirected donor lymphocyte infusion could reduce relapse of standardrisk acute leukemia patients after allogeneic hematopoietic stem cell transplantation. Blood. 2012;119:3256-62.

49. Lutz C, Massenkeil G, Nagy M, Neuburger S, Tamm I, Rosen O, et al. A pilot study of prophylactic donor lymphocyte infusions to prevent relapse in adult acute lymphoblastic leukemias after allogeneic hematopoietic stem cell transplantation. Bone Marrow Transplant. 2008;41:805-12.

50. Eefting M, Halkes CJ, de Wreede LC, van Pelt CM, Kersting S, Marijt EW, et al. Myeloablative T cell-depleted alloSCT with early sequential prophylactic donor lymphocyte infusion is an efficient and safe post-remission treatment for adult ALL. Bone Marrow Transplant. 2014;49:287-91.

51. Dominietto A, Pozzi S, Miglino M, Albarracin F, Piaggio G, Bertolotti F, et al. Donor lymphocyte infusions for the treatment of minimal residual disease in acute leukemia. Blood. 2007;109:5063-4.

52. Bader P, Kreyenberg H, Henze GH, Eckert C, Reising M, Willasch A, et al. Prognostic value of minimal residual disease quantification before allogeneic stem-cell transplantation in relapsed childhood acute lymphoblastic leukemia: the ALL-REZ BFM Study Group. J Clin Oncol. 2009;27:377-84.

53. Huang XJ, Wang Y, Liu DH, Xu LP, Chen H, Chen YH, et al. Modified donor lymphocyte infusion (DLI) for the prophylaxis of leukemia relapse after hematopoietic stem cell transplantation in patients with advanced leukemia-feasibility and safety study. J Clin Immunol. 2008;28:390-7.

54. Kang Y, Chao NJ, Aversa F. Unmanipulated or CD34 selected haplotype mismatched transplants. Curr Opin Hematol. 2008;15:561-7.

55. Chalandon Y, Passweg JR, Schmid C, Olavarria E, Dazzi F, Simula MP, et al. Outcome of patients developing GVHD after DLI given to treat CML relapse: a study by the Chronic Leukemia Working Party of the EBMT. Bone Marrow Transplant. 2010;45:558-64.

56. Peggs KS, Kayani I, Edwards N, Kottaridis P, Goldstone AH, Linch DC, et al. Donor lymphocyte infusions modulate relapse risk in mixed chimeras and induce durable salvage in relapsed patients after T-cell-depleted allogeneic transplantation for Hodgkin's lymphoma. J Clin Oncol. 2011;29:971-8.

57. Solomon SR, Sizemore CA, Zhang X, Brown S, Holland HK, Morris LE, et al. Preemptive DLI without withdrawal of immunosuppression to promote complete donor T-cell chimerism results in favorable outcomes for high-risk older recipients of alemtuzumab-containing reduced-intensity unrelated donor allogeneic transplant: a prospective phase II trial. Bone Marrow Transplant. 2014;49:616-21.

58. Steininger PA, Strasser EF, Weiss D, Achenbach S, Zimmermann R, Eckstein R. First comparative evaluation of a new leukapheresis technology in non-cytokine-stimulated donors. Vox Sang. 2014;106:248-55.

59. Schulz M, Bialleck $H$, Thorausch K, Bug G, Dunzinger U, Seifried E, et al. Unstimulated leukapheresis in patients and donors: comparison of two apheresis systems. Transfusion. 2014;54:1622-9.

60. Luznik L, O'Donnell PV, Symons HJ, Chen AR, Leffell MS, Zahurak M, et al. HLA-haploidentical bone marrow transplantation for hematologic malignancies using nonmyeloablative conditioning and high-dose, posttransplantation cyclophosphamide. Biol Blood Marrow Transplant. 2008;14:641-50.

61. Zeidan AM, Forde PM, Symons H, Chen A, Smith BD, Pratz K, et al. HLAhaploidentical donor lymphocyte infusions for patients with relapsed hematologic malignancies after related HLA-haploidentical bone marrow transplantation. Biol Blood Marrow Transplant. 2014;20:314-8.

62. Ghiso A, Raiola AM, Gualandi F, Dominietto A, Varaldo R, Van Lint MT, et al. DLI after haploidentical BMT with post-transplant CY. Bone Marrow Transplant. 2015;50:56-61.

63. Bierman PJ, Sweetenham JW, Loberiza FR Jr, Taghipour G, Lazarus HM, Rizzo JD, et al. Syngeneic hematopoietic stem-cell transplantation for non-Hodgkin's lymphoma: a comparison with allogeneic and autologous transplantation-The Lymphoma Working Committee of the International Bone Marrow Transplant Registry and the European Group for Blood and Marrow Transplantation. J Clin Oncol. 2003;21:3744-53.

64. Kolb HJ. Graft-versus-leukemia effects of transplantation and donor lymphocytes. Blood. 2008;112:4371-83.

65. Lokhorst HM, Schattenberg A, Cornelissen JJ, Thomas LL, Verdonck LF. Donor leukocyte infusions are effective in relapsed multiple myeloma after allogeneic bone marrow transplantation. Blood. 1997;90:4206-11.

66. Min CK, Kim DW, Lee JW, Min WS, Kim CC. Additional stem cell therapy for graft failure after allogeneic bone marrow transplantation. Acta Haematol. 2000;104:185-92.

67. Remberger $M$, Ringden $O$, Ljungman $P$, Hagglund $H$, Winiarski J, Lonnqvist $B$, et al. Booster marrow or blood cells for graft failure after allogeneic bone marrow transplantation. Bone Marrow Transplant. 1998;22:73-8.

\section{Submit your next manuscript to BioMed Central and we will help you at every step:}

- We accept pre-submission inquiries

- Our selector tool helps you to find the most relevant journal

- We provide round the clock customer support

- Convenient online submission

- Thorough peer review

- Inclusion in PubMed and all major indexing services

- Maximum visibility for your research

Submit your manuscript at www.biomedcentral.com/submit 